\title{
PENGEMBANGAN PRODUKTIVITAS PENGOLAH GULAMPO DI DESA CIKALONG KECAMATAN CIKALONG KABUPATEN TASIKMALAYA
}

\author{
${ }^{1}$ Hodidjah, ${ }^{2}$ Resa Respati, ${ }^{3}$ Dwi Alia, ${ }^{4}$ Pidi Mohamad Setiadi \\ 1,2,3,4 Program Studi PGSD UPI Kampus Tasikmalaya \\ Hodidjah2017@gmail.com
}

\begin{abstract}
Cikalong Village, Cikalong Subdistrict, Tasikmalaya Regency is one of the villages that has the potential to process natural resources around it. One of the biggest natural potentials is coconut. Coconut is one of the capital for business. One such effort is gulampo as a typical souvenir of Cikalong. Based on that, the team will implement it community service through counseling, training, and guidance for gulampo processors who usually market their production to the Cikalong $3 D$ souvenir shop. The target of PkM output is 1) Increasing knowledge, understanding and skills of gulampo processing including: HR Management, Promotion Management, Business Management, Financial Management 2) Availability of facilities and infrastructure to complete production 3) Physical evidence of product promotion.
\end{abstract}

Keywords: Gulampo Processor, Productivity.

\begin{abstract}
ABSTRAK
Desa Cikalong Kecamatan Cikalong Kabupaten Tasikmalaya salah satu desa yang mempunyai potensi untuk mengolah sumber daya alam di sekitarnya. Salah satu potensi alam terbesar di sana adalah kelapa. Kelapa menjadi salah satu modal untuk usaha. Salah satu usaha tersebut adalah gulampo sebagai oleh-oleh khas Cikalong. Berdasarkan hal itu, maka tim akan melaksanakan Pengabdian kepada Masyarakat $(\mathrm{PkM})$ melalui kegiatan penyuluhan, pelatihan, dan pembinaan terhadap para pengolah gulampo yang biasa memasarkan produksinya ke toko oleh-oleh 3D Cikalong. Target luaran PkM ini adalah 1) Meningkatkan pengetahuan, pemahaman serta keterampilan pengolah gulampo meliputi: Manajemen SDM, Manajemen promosi, Manajamen usaha, Manajemen keuangan 2) Tersedianya sarana dan prasarana untuk melengkapi produksi 3) Dihasilkannya bukti fisik bentuk promosi produk.
\end{abstract}

Kata Kunci: Pengolah Gulampo, Produktivitas.

\section{PENDAHULUAN}


(Michael:2000) mengemukakan bahwa ekonomi memiliki tugas untuk memberi prinsip yang rasional bagi bisnis sebagai kegiatan ekonomi, sehingga kegiatan ekonomi tersebut tidak hanya mengarah diri pada kebutuhan hidup manusia perorang dan jangka pendek saja, tetapi juga memberi surplus bagi kesejahteraan banyak orang dalam Negara. Pada tahun 1983, pemerintah secara konsisten telah melakukan berbagai upaya deregulasi sebagai upaya penyesuaian struktural dan restrukturisasi perekonomian. Namun, banyak yang mensinyalir deregulasi di bidang perdagangan dan investasi tidak memberi banyak keuntungan bagi perusahaan kecil dan menengah; bahkan justru perusahaan besar dan konglomeratlah yang mendapat keuntungan.

Ada banyak karakteristik dari usaha kecil ini, namun secara umum usaha kecil ini memiliki karakteristik yang seragam. Pertama, tidak adanya pembagian tugas yang jelas antara bidang administrasi dan operasi. Kebanyakan industri kecil dikelola oleh perorangan yang merangkap sebagai pemilik sekaligus pengelola perusahaan, serta memanfaatkan tenaga kerja dari keluarga dan kerabat dekatnya saja. Kedua, rendahnya akses industri kecil terhadap lembaga-lembaga kredit formal sehingga mereka cenderung menggantungkan pembiayaan usahanya dari modal sendiri atau sumbersumber lain seperti keluarga, kerabat, pedagang perantara, bahkan rentenir. Ketiga, sebagian besar usaha kecil ditandai dengan belum dipunyainya status badan hukum. Keempat, dilihat menurut golongan industri tampak bahwa hampir sepertiga bagian dari seluruh industri kecil bergerak pada kelompok usaha industri makanan, minuman dan tembakau.

Hal tersebut menjadi sebuah tantangan dalam meningkatkan kemajuan usaha kecil. Banyak sekali faktor yang menjadi penghambat kemajuan usaha kecil, sehingga disaat hendak meningkatkan atau mengembangkan usaha kecil tersebut tantangannya memang sangatlah berat. Selain hal-hal yang telah terurai di atas, ada juga faktor lainnya,diantaranya lemahnya kemampuan manajerial, keterampilan dan keterbatasan sumber daya manusia yang ada. Permasalahan yang mendasar dari perkembangan usaha kecil ini adalah kelemahan dalam memperoleh peluang pasar dan pangsa pasar serta lemahnya di bidang organisasi dan manajemen sumber daya manusia.

Di Desa Cikalong Kecamatan Cikalong Kabupaten Tasikmalaya, usaha kecil yang berkembang di masyarakat masih sangat kurang, padahal daerah tersebut cukup potensial untuk berkembang pesat dalam hal peningkatan ekonomi masyarakat melalui pengolahan potensi alam sekitarnya seperti produksi gulampo. Berdasarkan hasil survey lapangan, hampir sebagian besar masyarakat desa Cikalong bermata pencaharian sebagai petani. Mereka memanfaatkan lahan pertanian dengan ditanami pohon kelapa, yang kemudian diolah menjadi gula dan gulampo. Sumber daya alam Desa Cikalong ini masih terjaga dan melimpah karena masyarakat Desa Cikalong selalu menjaga dan memanfaatkan alam sebagai komponen utama untuk memenuhi kebutuhan hidupnya. Namun, kualitas sumber daya manusia masyarakat Desa Cikalong masih kurang, terutama dalam hal strategi pemasaran dan peningkatan produk olahan dari kelapa menjadi gulampo yang menjadi makanan khas daerah tersebut. Maka, Eksistensi UU No. 6 Tahun 2014 secara tegas menjelaskan mengenai pemberdayaan masyarakat sebagaimana tertuang dalam pasal 1 ayat 12. Pasal tersebut berbunyi: "Pemberdayaan masyarakat desa adalah upaya mengembangkan kemandirian dan kesejahteraan masyarakat dengan meningkatkan pengetahuan, sikap, keterampilan, perilaku, kemampuan, kesadaran, serta memanfaatkan sumber daya melalui penetapan kebijakan, program, kegiatan, dan pendampingan yang sesuai dengan esensi masalah dan prioritas kebutuhan masyarakat desa.”

Merujuk pada peraturan perundang-undangan tentang pemberdayaan masyarakat dan melihat permasalahan yang dihadapi oleh para pengolah gulampo, maka dari itu tim pengabdian dari UPI Kampus Tasikmalaya merasa perlu untuk memberikan solusi dengan melaksanakan pengabdian berupa penyuluhan ataupun pelatihan kepada para pengolah gulampo di desa Cikalong. Dalam hal ini program desa binaan yang kami usung mengarah kepada peningkatan produktivitas masyarakat Desa Cikalong dalam pengolahan makanan khas gulampo yang belum diketahui banyak orang. Selain itu, pemberdayaan sumber daya manusia dan teknologi guna memasarkan produk secara meluas sampai ke daerah perkotaan.

\section{METODE}


Adapun model pelatihan yang digunakan terkait pengembangan produktivitas pengolah gulampo adalah model pelatihan dari Treadway Pakker dengan tahapan: 1) Analisis kebutuhan merupakan tahap awal sebagai upaya menentukan program kegiatan pengabdian, analisis kebutuhan pengolah gulampo antara lain: Proses analisis dilakukan dengan identifikasi masalah menggunakan teknik analisis SWOT kekuatan (strength), kelemahan (weaknesses), peluang (opportunities), dan ancaman (threats); 2) Tujuan Pelatihan dan Pembinaan (Develop Training Objective); 3) Merancang Kurikulum Pelatihan (Designing Training Curriculum); 4) Metode Pelatihan (Designing Training Methode); 5) Pendekatan Evaluasi Pelatihan (Designing Training Evaluation Approach); 6) Implementasi Program (Implement Training Program); 7) Pengukuran Hasil Pelatihan (Measure Training Result). Adapun khalayak sasaran dari program pengabdian ini yaitu mitra terkait dan masyarakat Desa Cikalong Kecamatan Cikalong Kabupaten Tasikmalaya. Langkah-langkah kegiatan pengabdian kepada masyarakat ini adalah 1) Persiapan kegiatan pengabdian, 2) Pelaksanaan kegiatan pengabdian antara lain : a) Pelatihan bentuk promosi b) Penyuluhan manajemen SDM dan usaha, c) Penyuluhan manajemen keuangan, dan d) Penyediaan alat dan bahan. 3) Monitoring dan evaluasi program pengabdian; dan 4) Tindak lanjut.

\section{HASIL DAN PEMBAHASAN}

\section{a. Penyuluhan Motivasi Wirausaha}

Kegiatan ini dilaksanakan 15 Agustus 2018 bertempat di rumah Ibu Isoh dengan pemateri Bapak Ilham Mauludin, S.Pd, serta dihadiri oleh peserta dari mitra kelompok usaha pengolah gulampo. Pada pertemuan pertama ini materi yang disampaikan yaitu tentang motivasi berwirausaha yang esensinya mendiskusikan pengalaman-pengalaman para pengusaha yang sudah sukses di bidangnya masingmasing. Selain itu dibahas juga tentang materi manajemen usaha baik itu dari optimalisasi sumber daya manusia, pemilihan jenis usaha yang akan digeluti ataupun kiat-kiat menjadi pengusaha sukses.

\section{b. Penyuluhan Manajemen Usaha dan Keuangan}

Penyuluhan selanjutnya dilaksanakan pada tangal 23 September 2018 dan 21 Oktober 2018 dengan pemateri yaitu Bapak Dindin Abdul Muiz Lidinillah, S.Si., SE., M.Pd. Materi yang dibahas adalah mengenai perencanaan bisnis agar kelompok usaha ini dapat mengembangkan usahanya untuk jangka panjang dan manajemen keuangan baik itu cara pengelolaan keuangan, sumber-sumber penghasilan ataupun pembuatan laporan keuangan. Sehingga output dari kegiatan pelatihan ini adalah kelompok usaha pengolah gulampo dapat lebih termotivasi lagi untuk mengembangkan usaha tentunya dengan manajemen usaha dan perencanaan bisnis yang baik serta manajemen keuangan yang baik pula. Dalam penyuluhan ini juga diberikan motivasi dan usulan beberapa inovasi yang bisa dilakukan untuk peningkatan produk olahan gulampo. Inovasi itu diantaranya bisa dilakukan dengan variant rasa gulampo yang bisa menarik minat para pembeli, terutama para generasi muda.

\section{c. Pelatihan Manajemen Promosi}

Kegiatan manajeman promosi dilakukan pada tanggal 02 Desember 2018 dengan pemateri Bapak Ilham Mauludin, S.Pd. Adapun untuk materi yang disampaikan dalam penyuluhan manajemen promosi yaitu: a) Apa itu promosi b) Fungsi promosi c) Strategi promosi d) Tujuan promosi e) Caracara promosi f) Perbedaan promosi dan pemasaran. Pada kegiatan ini dibahas lebih jauh materi mengenai bagaimana promosi produksi dilakukan dengan berbagai media yang tersedia seperti pamflet, instagram, FB, dan beberapa media lain yang sekarang sedang booming di masyarakat. Hal ini diharapkan bisa memasarkan lebih luas produk gulampo ke masyarakat.

\section{d. Penyediaan Alat dan Bahan}

Sarana dan Prasarana (Alat dan Bahan) yang diberikan kepada mitra tentunya disesuaikan dengan kebutuhan mitra berdasarkan ajuan yang disampaikan oleh mitra. Pengadaan alat dan bahan ini tentunya disesuaikan dengan anggaran yang tersedia. Dengan adanya sarana prasarana ini dapat 
memperlancar usaha khusunya untuk mengolah gulampo. Alat yang diberikan berupa wajan besar, serok kayu, dan alat untuk mencetak gulampo.

\section{SIMPULAN}

Dari pengabdian ini dapat ditarik kesimpulan bahwa masyarakat Desa Cikalong Kecamatan Cikalong Kabupaten Tasikmalaya, khususnya masyarakat pengolah gulampo sangat memerlukan dan merespon positif mengenai program PkM Desa binaan dengan fokus pengabdian kepada pengembangan produktivitas kelompok pengolah gulampo. Kegiatan PkM Desa Binaan ini meningkatkan motivasi berwirausaha, manajemen bisnis, dan manajemen keuangan. Selain itu dilakukan pula pelatihan untuk meningkatkan promosi usaha gulampo tersebut, sehingga bisa lebih dikenal oleh masyarakat luas.

Kegiatan PkM Desa Binaan ini semakin lengkap dengan diberikannya sarana prasana pendukung untuk pembuatan gulampo yang cukup refresentatif dalam upaya melancarkan produksi gulampo. Pemberian alat itu berupa wajan besar, serokan kayu, dan cetakan kayu.

Dari hasil kegiatan pengabdian yang telah dilaksanakan ini, ada beberapa saran dan rekomendasi yang harus diperhatikan di antaranya :

1. Bagi Pemerintah Desa Cikalong Kecamatan Cikalong Kabupaten Tasikmalaya, diharapkan program pengembangan kelompok usaha pengolah gulampo ini dilanjutkan menuju kemandirin desa sebagaimana yang tertulis dalam visi Pemerintahan Jawa Barat.

2. Bagi kelompok usaha, semoga dapat memanfaatkan sarana dan prasarana yang telah tersedia dengan sebaik-baiknya dan menjadikan pelatihan-pelatihan sebagai bekal dasar dalam mengembangkan kelompok usaha.

3. Bagi masyarakat pada umumnya, diharapkan ikut berpartisipasi aktif dalam meneruskan kegiatan pengabdian ini secara optimal di masa yang akan datang.

\section{DAFTAR PUSTAKA}

1. Anoraga, Pandji. (2008). Manajemen Bisnis. Jakarta : Rineka Cipta.

2. Husanei, Martini. (2001). Potensi Daerah di Otonomi Daerah; Peluang dan Tantangan Otonomi Daerah. Jakarta: PT. Permata Artistika Kreasi.

3. LPPM UPI. (2017). Panduan Pelaksanaan Kegiatan Penelitian dan Pengabdian Kepada Masyarakat Di Lingkungan Universitas Pendidikan Indonesia Tahun 2017. Bandung: UPI.

4. Michael P. Todara. (2000). Ekonomi Untuk Negara Berkembang. Jakarta: Bumi Aksara

5. Undang-Undang Republik Indonesia Nomor 6 Tahun 2014 Tentang Desa

6. Wahjono S. Imam. (2008). Manajemen Tata Kelola Organisasi Bisnis. Jakarta : Indeks. 